\title{
30 DE SETEMBRO, DIA DA SECRETÁRIA: ANÁLISE DISCURSIVO-IMAGÉTICO-TEXTUAL DE PUBLICIDADE ON-LINE DA UNIMED ARARAQUARA
}

\author{
Ana Carolina Gonçalves Reis ${ }^{i}$ \\ Anna Clara Arcanjo Fonsecaii
}

Resumo: Este estudo apresenta uma análise discursivo-imagético-textual de uma publicidade on-line veiculada no Dia da Secretária - 30 de setembro - de 2011 pela "Unimed Araraquara". Como aporte teórico-metodológico, valemo-nos da Teoria Semiolinguística (CHARAUDEAU, 2008b). Nosso intento foi identificar os imaginários sociodiscursivos (CHARAUDEAU, 2008a; REIS, 2012) construídos acerca da profissão e do profissional da área secretarial e verificar se coadunavam ou iam de encontro aos usualmente averiguados na sociedade. Identificamos, pois, uma dualidade de imaginários: alguns, socialmente cristalizados, como no que tange ao gênero (feminino) e à não diferenciação das profissões de secretariado e secretariado executivo, foram observados; mas, por outro lado, foi curioso constatar também uma veiculação de imaginários da profissão ancorados na Lei 9261/96, relacionados aos saberes de conhecimento, tais como os concernentes à assistência e ao assessoramento a executivos, por exemplo.

Palavras-chave: Análise do Discurso. Teoria Semiolinguística. Imaginários sociodiscursivos. Secretariado.

\begin{abstract}
This study presents a discursive-imagistic-textual analysis of an online advertisement published in 2011 on the Secretary's Day - September 30th -by "Unimed Araraquara". As a theoretical and methodological approach, we drew upon Semiolinguistics (CHARAUDEAU, 2008b). We sought to identify the sociodiscursive imaginaries (CHARAUDEAU, 2008a; REIS, 2012) construed regarding the profession and the secretarial professional and check if they reinforce or refute the ones commonly found in our society. We were then able to identify a duality of imaginaries: some already crystallized, related to the (female) gender and the non-differentiation of secretarial professions; and other ones based on Brazilian Law 9261/96, related to knowledge, such as those concerning assistance and advice to executives, for example.
\end{abstract}

Keywords: Discourse Analysis. Semiolinguistics. Sociodiscoursives imaginaries. Secretariat.

i Mestre em Estudos Linguísticos pela Universidade Federal de Minas Gerais (UFMG). Docente da Universidade Federal de Viçosa (UFV). E-mail: carolinareis@ufv.br.

ii Bacharel em Secretariado Executivo Trilíngue pela Universidade Federal de Viçosa (UFV). E-mail: annacl.fonseca@gmail.com. 
EID\&A - Revista Eletrônica de Estudos Integrados em Discurso e Argumentação, Ilhéus, n. 12, jul/dez.2016.

\section{Introdução}

A origem do secretariado, segundo Sabino e Rocha (2004), pode ser associada à Dinastia Macedônica. Nas batalhas para suas conquistas territoriais, o Imperador Alexandre Magno valia-se de secretários, que o auxiliavam tanto na composição dos exércitos quanto nos registros escritos das conquistas. Para se tornar um secretário, o indivíduo precisava frequentar renomadas escolas; seguir tal carreira significava, pois, pertencer à classe oficial culta, ser isento do trabalho servil e ter a possibilidade de ocupar cargos públicos elevados, conforme pontuam aqueles autores.

Durante muito tempo, até o século XX, apenas os homens ocupavam os cargos de secretários. O ingresso da mulher na carreira secretarial só foi ocorrer alguns anos mais tarde, na época da Primeira Guerra Mundial (19141918). A partir de então, com a ida dos homens para atuarem nos campos de batalha, as mulheres começaram a exercer a função, a qual passou a ser categorizada como eminentemente feminina.

De acordo com Reis (2012), a inserção da mulher no ofício traz uma nova configuração para a profissão. Nos anos 1950, no Brasil, por exemplo, havia uma grande presença de secretárias nas mais diversas organizações, executando tarefas majoritariamente de ordem técnica (como datilografia, anotações de recados e atendimento telefônico). Já em 1960, a profissional era vislumbrada pelas características estéticas (atreladas à mulher) e ter uma secretária era sinal de prestígio para o executivo.

Cabe destacar que ofício secretarial, em nosso país, compete aos profissionais de secretariado e de secretariado executivo, diferenciação estabelecida por lei na década de 1980. A distinção das atribuições de ambos se dá no Art. $4^{\circ}$ da Lei de Regulamentação da Profissão, $n^{\circ} 7377$, de 30-9-85, complementada pela Lei $\mathrm{n}^{\circ}$ 9261, de 10-01-96, que dispõe sobre o exercício dessas categorias profissionais'. De modo geral, podemos dizer que o secretário executa funções de caráter mais técnico e o secretário executivo, de caráter mais gerencial.

Nesse viés, tomando a profissão secretarial como foco de nossa pesquisa, propomos o presente estudo. Nosso intento é analisar uma publicidade on-line da empresa brasileira de planos de saúde "Unimed Araraquara", publicidade essa veiculada no "Dia da Secretária" do ano de 2011

\footnotetext{
${ }^{1}$ Fonte: <http://www.fenassec.com.br/b_osecretariado_lei_regulamentacao.html\#lei>. Acesso em: 27 set. 2016.
} 
EID\&A - Revista Eletrônica de Estudos Integrados em Discurso e Argumentação, Ilhéus, n. 12, jul/dez.2016.

para saudar os/as profissionais da área. Buscamos, especificamente, investigar os imaginários do/da profissional veiculados no gênero em questão e analisar as características atribuídas à profissão secretarial, de modo a averiguar se os imaginários se baseiam ou não nos conceitos socialmente cristalizados em torno da profissão - relacionados ao gênero feminino, à não distinção entre secretário e secretário executivo e às características tecnicistas, comumente atreladas a essa ocupação.

A base para o trabalho com nosso corpus foi a Teoria Semiolinguística de Charaudeau (2008b), para definir a situação de comunicação, os sujeitos da linguagem e o gênero discursivo. Valemo-nos, ademais, dos modos de organização do discurso propostos por esse autor para analisar o discurso dessa publicidade, cabe ressaltar, tanto no artefato textual como no imagético. Desse modo, trabalhamos sob a perspectiva da discursividade de cores e de formas (REIS, 2012).

Passemos agora à fundamentação teórica de nossa pesquisa.

\section{Referencial Teórico}

\subsection{Teoria Semiolinguística e os Sujeitos da Linguagem}

Para definirmos as instâncias de produção e recepção do ato de linguagem, utilizamos os preceitos da Teoria Semiolinguística de Charaudeau (2008b).

Essa teoria considera a linguagem como um processo sociointeracional no qual se encontram quatro sujeitos. O EUc é o sujeito produtor da fala; já o EUe é uma imagem de enunciador construída por esse sujeito produtor da fala (EUc), que representa seu traço de intencionalidade no ato de produção (CHARAUDEAU, 2008b). O TUd é o interlocutor projetado pelo EUc como destinatário ideal, adequado ao seu ato de enunciação; e o TUi é o sujeito responsável pelo processo de interpretação. Para o autor, haverá êxito no processo comunicacional se houver uma convergência entre o TUd e o TUi.

No processo sociointeracional do ato de linguagem, os seres sociais estabelecem um acordo quanto ao uso dos elementos de sua comunicação, por isso, o EUc supõe que o outro possui uma competência linguageira de reconhecimento análoga à sua, conforme Charaudeau (2008b). O autor afirma que, então, todo ato de comunicação pressupõe um determinado contrato social. Além disso, para que suas intenções sejam colocadas em cena, o EUc 
utiliza estratégias, ou seja, organiza e encena suas intenções de forma a produzir determinados efeitos - de persuasão ou de sedução - sobre o TUi, para que este se identifique com o destinatário ideal, o TUd (CHARAUDEAU, 2008b). Desse modo, tem-se que o contrato de comunicação, consoante Pauliukonis e Gouvêa (2012), é o que possibilita aos parceiros se reconhecerem um ao outro por meio de traços identitários. Ademais, tal contrato reúne as condições mínimas necessárias para a realização do ato de linguagem, que se compõe de um espaço de regras que não podem ser infringidas pelos parceiros - pois, caso contrário, pode não haver êxito na comunicação - e de um espaço de manobras, que compreende os diferentes tipos de configurações discursivas (estratégias) de que o EUc se utiliza para atingir seus objetivos.

\subsection{Gênero}

De acordo com Charaudeau (2004), para a definição do gênero discursivo, é preciso considerar as coerções contratuais concernentes ao ato linguageiro, às restrições da organização discursiva e às marcas formais de um texto. Desse modo, o autor preconiza que o gênero do discurso é situacional, elencando os seguintes elementos a serem tomados na caracterização genérica: a finalidade do ato de linguagem numa dada situação de comunicação, a identidade dos parceiros, o propósito comunicativo e as circunstâncias e condições materiais da comunicação.

\subsection{Modos de Organização do Discurso}

O EUc, diante das restrições que configuram o contrato de comunicação, utiliza princípios (modos) de organização da matéria linguageira em seu projeto de fala. Os Modos de Organização do Discurso (MOD) constituem-se, assim, de formas de organização da materialidade linguística e são dependentes da finalidade comunicativa do sujeito falante (CHARAUDEAU, 2008b). Esses procedimentos são expressos em quatro modos: o enunciativo, o descritivo, o narrativo e o argumentativo, cada um com sua função, que se relaciona à finalidade discursiva do projeto de fala do locutor: enunciar, descrever, narrar e argumentar (PAULIUKONIS e GOUVÊA, 2012).

Consoante Charaudeau (2008b), os MOD podem assim ser descritos: 0 modo enunciativo aponta a posição do sujeito enunciador em relação ao 
EID\&A - Revista Eletrônica de Estudos Integrados em Discurso e Argumentação, Ilhéus, n. 12, jul/dez.2016.

interlocutor, ao seu próprio discurso e a outros discursos. Ele intervém e comanda os outros modos. Já o modo descritivo possibilita fazer existir os seres do mundo, ao nomeá-los, localizá-los e qualificá-los de modo particular. O modo narrativo, por sua vez, possibilita organizar a sucessão de ações e de eventos nos quais esses seres estão envolvidos. Por fim, o modo argumentativo possibilita estabelecer as relações que envolvem um sujeito que desenvolve uma proposição ou uma convicção e outro que é alvo dessa argumentação/persuasão.

\subsection{Imaginários Sociodiscursivos}

Os imaginários sociodiscursivos são representações construídas pelo dizer, configurando-se como perceptíveis e identificáveis nos e pelos discursos que circulam nos grupos sociais. Transformando a realidade em real significante, eles resultam de diferentes tipos de saberes: saberes de crença e de conhecimento (CHARAUDEAU, 2008a).

Segundo Charaudeau (2008a), as diferenças entre tais saberes se devem às formas particulares como cada um toma a relação homem/mundo. Nos saberes de conhecimento, ocorre um processo de verificação que apresenta tais saberes como verdades objetivas. Nesse caso, o mundo está se impondo ao homem. Com relação aos saberes de crença, ocorre o inverso: é o homem que se impõe ao mundo. Trata-se de avaliações subjetivas dos sujeitos sobre os fatos do mundo. Logo, os primeiros objetivam confirmar uma verdade acerca dos fenômenos vivenciados, e os segundos vinculam-se à interpretação do mundo baseada nas avaliações, apreciações e valorações subjetivas.

Constituídos pelas representações sociais, os imaginários englobam explicações, enunciados, conceitos, ideias, informações, opiniões, atitudes e valores circulantes em uma dada sociedade. Desse modo, os imaginários sociodiscursivos encaixam-se como uma categoria analítico-discursiva para o presente trabalho pelo fato de ser possível evidenciá-los tanto nas manifestações verbais como nas produções imagéticas, refletindo a construção e a interpretação da realidade pelos sujeitos (REIS, 2012).

\subsection{Imagens e Cores}

Partindo da Teoria Semiolinguística aplicada ao estudo das imagens, Medina (2013) afirma que a significação discursiva é resultante de dois 
EID\&A - Revista Eletrônica de Estudos Integrados em Discurso e Argumentação, Ilhéus, n. 12, jul/dez.2016.

componentes: o discursivo e o situacional, os quais determinam as possibilidades interpretativas da imagem pelo TUi. $O$ processo de entendimento dos possíveis efeitos de sentido de uma imagem está diretamente relacionado, logo, à situação de comunicação em que o leitor da imagem está inserido. Ademais, os conhecimentos e as crenças deste vão orientar para o modo como a imagem é interpretada. $O$ autor pondera, ainda, que os propósitos comunicativos da instância produtora - do EUc - também irão direcionar os efeitos de sentido instaurados pela imagem.

Em relação às cores, convém esclarecer que seu uso advém desses propósitos comunicativos do EUc (como, por exemplo, informar e/ou seduzir o TUi); elas se configuram, portanto, como formas de significar (REIS, 2012). Para Guimarães (2000), a significação das cores advém de suas várias aplicações em diversos tipos de objetos; elas são tomadas, pois, como informação. Dito de outro modo, esse autor preconiza que a cor é aplicada sempre com determinada intenção, instaurando determinadas possibilidades interpretativas ao objeto.

\subsection{As Profissões de Secretariado/Secretariado Executivo e o Dia da Secretária}

De acordo com o Art. $4^{\circ}$ da Lei de Regulamentação $n^{\circ} 7377$, de 30-9-85, complementada pela Lei $n^{\circ}$ 9261, de 10-01-96, que dispõe sobre o exercício das ocupações de secretário e secretário executivo no Brasil, temos que as competências exigidas para essas duas categorias profissionais são distintas. Dessa maneira, são atribuições do secretário:

[...] organização e manutenção dos arquivos da secretaria; classificação, registro e distribuição de correspondência; redação e datilografia de correspondência ou documentos de rotina, inclusive em idioma estrangeiro; execução de serviços típicos de escritório, tais como recepção, registro de compromissos, informações e atendimento telefônico (BRASIL, 1996, artigo $5^{\circ}$ ).

O secretário seria, assim, aquele profissional que desempenha atividades de ordem técnica, sendo, inclusive, um profissional cuja formação característica é em nível de segundo grau.

Conforme a mesma Lei, cabe ao Secretário Executivo, dentre outras, as atribuições:

[...] planejamento, organização e direção de serviços de secretaria; assistência e assessoramento direto a executivos; redação de textos profissionais 
EID\&A - Revista Eletrônica de Estudos Integrados em Discurso e Argumentação, Ilhéus, n. 12, jul/dez.2016.

especializados, inclusive em idioma estrangeiro; versão e tradução em idioma estrangeiro, para atender às necessidades de comunicação da empresa; registro e distribuição de expediente e outras tarefas correlatas; orientação da avaliação e seleção da correspondência para fins de encaminhamento à chefia [...] (BRASIL, 1996, artigo $4^{\circ}$ ).

Evidencia-se, assim, que o secretário executivo detém competências de caráter mais gerencial, caracterizado como um profissional em nível de terceiro grau.

No que se refere ao Dia da Secretária, cabe pontuar que no ano de 1950, conforme esclarecem Sabino e Rocha (2004), em comemoração aos 100 anos do nascimento de Lílian Sholes - filha do inventor da máquina de escrever, Christopher Sholes -, considerada a primeira datilógrafa, as empresas fabricantes de máquinas de escrever organizaram, em 30 de setembro, o primeiro concurso de datilógrafos - uma das denominações que o profissional de secretariado teve ao longo da sua história, já que esse equipamento foi, durante muitos anos, seu instrumento de trabalho. Como a maior parte do público presente no concurso foi do sexo feminino, a data ficou conhecida como o Dia da Secretária (REIS, 2012). Embora, como vimos, haja uma diferenciação entre os ofícios de secretariado e secretariado executivo, é importante destacar que nesse dia é celebrada a profissão secretarial, independentemente da categoria. Ademais, mesmo havendo mulheres e homens atuando na área, o dia é (até hoje) alcunhado no feminino.

\section{Descrição do Objeto de Estudo}

O nosso objeto de estudo constituiu-se de uma publicidade veiculada online no Dia da Secretária pela Unimed Araraquara. Fundada em 15 de maio de 1971, essa filial da empresa brasileira de planos de saúde Unimed tem como objetivo "proporcionar a seus beneficiários atendimento médico-hospitalar de qualidade, respeitando a livre escolha pelo beneficiário e garantindo ao médico a valorização do seu trabalho" (UNIMED ARARAQUARA).

Em 30 de setembro de 2011, tal filial divulgou em sua página eletrônica uma publicidade objetivando parabenizar a profissional da área secretarial pela data comemorativa. Conforme é possível averiguar a seguir, a publicidade é composta de imagens e textos, ou seja, de artefato imagético e de artefato verbal, ao que se denomina, na esteira de Reis (2012), de gênero híbrido. 


\section{Figura 1 - Objeto de estudo}

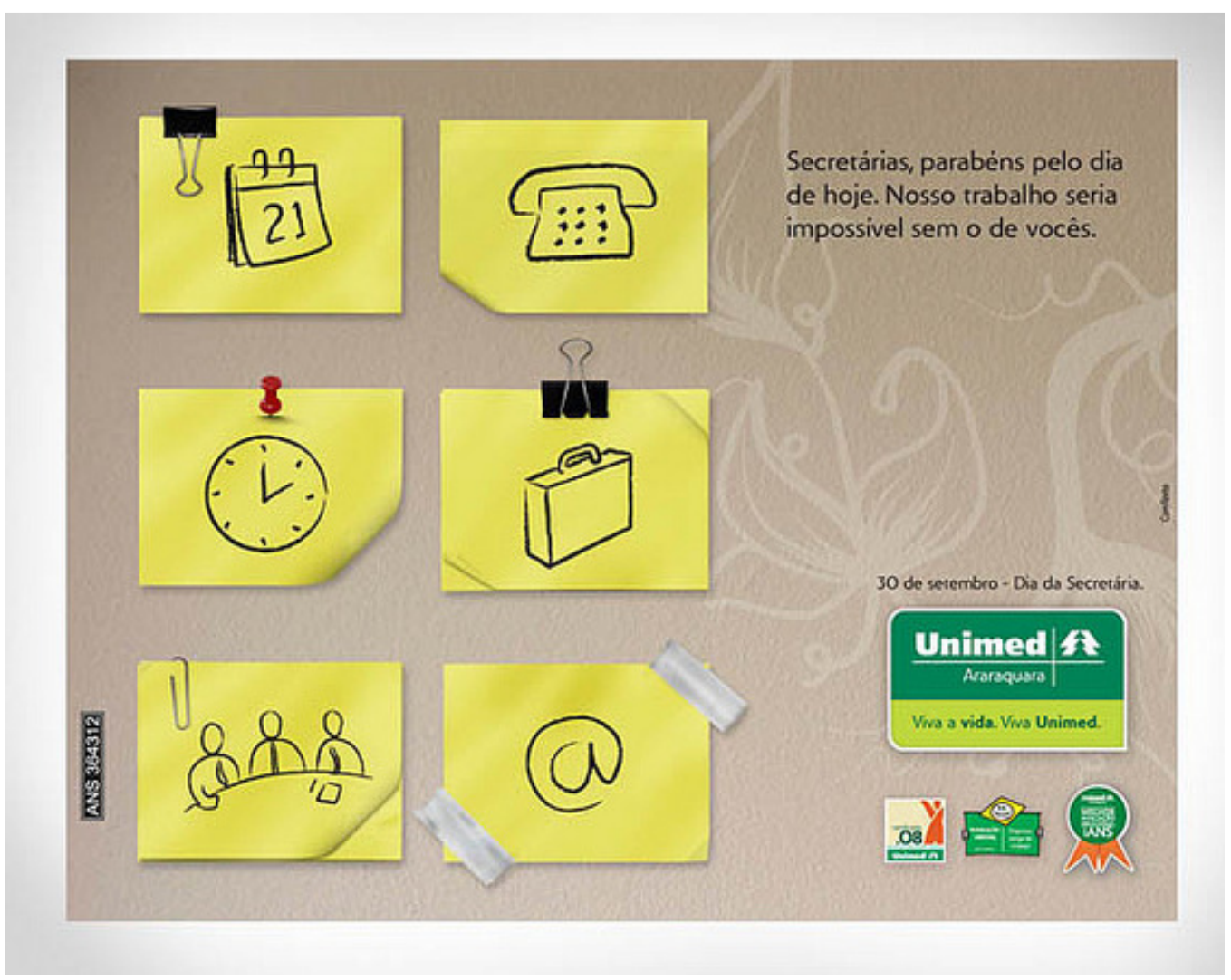

Fonte: https://www.flickr.com/photos/gabrielportifolio/5463000106/?rb=1

\section{Análise}

Com base nas abordagens trazidas em nosso referencial teórico, definimos como gênero de nosso objeto de estudo a publicidade. A finalidade do ato de linguagem em questão é cumprimentar a profissional pelo Dia da Secretária: "Secretárias, parabéns pelo dia de hoje"; já seu propósito comunicativo é promover a imagem da organização e divulgar a marca da empresa, o que pode ser comprovado na utilização do logotipo da organização, com suas cores características (o verde e o branco), logo abaixo da sentença "30 de setembro - Dia da Secretária". É possível depreendermos que tal alocação do logotipo remete a uma assinatura, ou seja, evidencia a enunciadora, a Unimed. No que se refere às circunstâncias e condições de comunicação, temos que o suporte de tal publicidade é uma plataforma virtual, posto que fora veiculada on-line. 
EID\&A - Revista Eletrônica de Estudos Integrados em Discurso e Argumentação, Ilhéus, n. 12, jul/dez.2016.

Convém explanar que, como pontua Melo (2011) em seus estudos, o discurso publicitário possui uma finalidade essencialmente argumentativa: persuadir, exercer influência. No caso da publicidade que trazemos, dizemos que a Unimed busca exercer influência junto a seu TUd - profissionais de secretariado e de secretariado executivo - na medida em que mostra ser uma empresa que reconhece e valoriza o trabalho secretarial. Depreendemos isso a partir do enunciado: "Nosso trabalho seria impossível sem o de vocês". Assim o fazendo, a Unimed busca agregar para si uma imagem positiva.

No que se refere à situação de comunicação (CHARAUDEAU, 2008b), definimos os seguintes parceiros/sujeitos do ato de linguagem: o EUc seria a Unimed, instância compósita que abarca todos os seus funcionários; no EUc também inclui-se a equipe responsável pela criação da publicidade. Já o EUe seria a própria Unimed, que assina a publicidade, sendo a responsável pelo dizer. O TUd, por sua vez, seria o público a quem essa publicidade visa atingir, ou seja, as secretárias e as secretárias executivas internautas - visto que o gênero utilizado no texto foi o feminino e que a publicidade fora veiculada online. O TUi, finalmente, são todas as pessoas que efetivamente visualizaram a publicidade.

É importante aqui observarmos a utilização da palavra "secretária", no feminino, o que exclui os profissionais homens, nessa situação de comunicação, como TUd. Em nosso entendimento, isso corrobora os imaginários sociodiscursivos que tomam $\mathrm{o}$ profissional de secretariado/secretariado executivo exclusivamente como do sexo feminino, imaginários esses latentes após a inserção da mulher na carreira secretarial, quando da Primeira Guerra Mundial, e ainda evidenciados nos dias atuais, conforme Reis (2012).

Para Charaudeau (2008b), o EUe vale-se de estratégias discursivas determinadas de acordo com suas intenções de persuadir seu TUd. Como uma das estratégias, podemos citar o fato de o enunciador apoiar-se numa posição de autoridade institucional (a empresa Unimed), para fazer a sua declaração. Paralelamente, busca que o Tud identifique-se na representação de secretária do anúncio e se sinta parabenizado pelo seu dia. Além disso, entendemos que a empresa reconhece publicamente a importância da atividade secretarial, haja vista o fragmento: "Nosso trabalho seria impossível sem o de vocês", o qual correlaciona o trabalho realizado pela organização e o dessas profissionais. 
EID\&A - Revista Eletrônica de Estudos Integrados em Discurso e Argumentação, Ilhéus, n. 12, jul/dez.2016.

À esquerda desses dizeres, temos desenhos em papéis amarelos na publicidade, como que elencando algumas atribuições atreladas ao profissional da área secretarial. Nesse viés, identificamos, no que diz respeito aos Modos de Organização do Discurso (MOD), dois deles: o descritivo e o enunciativo (para além do argumentativo, conforme explanamos). Podemos dizer que, nas imagens, a descrição é evidenciada nas ferramentas de trabalho: calendário, relógio, telefone, maleta e “@” (simbolizando o e-mail). Ainda, pode ser confirmada em uma espécie de reunião ilustrada. Esses artefatos icônicos comumente evocam imaginários concernentes ao cotidiano do secretariado.

O MOD Descritivo caracteriza-se por três componentes: nomeação, localização/situação e qualificação (CHARAUDEAU, 2008b), todos verificados no objeto de estudo (nos componentes verbais e não verbais). A nomeação, ou seja, a identificação do sujeito, é averiguada na utilização das palavras "Secretária e Secretárias", bem como "Unimed", dando existência aos seres, fazendo-os significantes; já a localização/situação, que define a posição que os seres ocupam no espaço/tempo, é dada pela Unimed, uma vez que esta parabeniza as secretárias que trabalham na empresa; e, finalmente, a qualificação, que confere um sentido particular aos seres, é dada pelas ilustrações nos papéis amarelos, as quais qualificam as secretárias ao elencar suas atribuições profissionais.

Em relação ao MOD Enunciativo, nós o constatamos na identificação da posição do enunciador em relação ao interlocutor e ao discurso, aqui verificada na relação Unimed como enunciadora e responsável pelo conteúdo da publicidade e as secretárias como destinatárias: "Secretárias, parabéns pelo dia de hoje", trecho em que evidenciamos o modo alocutivo. Em: "Nosso trabalho seria impossível sem o de vocês", o enunciador se coloca no dizer; temos, portanto, o modo elocutivo. Finalmente, em "30 de setembro - Dia da Secretária", notamos o modo delocutivo, já que há uma referência a um terceiro, sem uma alusão ao locutor (EU) ou ao interlocutor (TU).

No que se refere ao componente imagético da publicidade, como o dissemos anteriormente, as ilustrações das atividades secretariais figuram em blocos ou papéis adesivos de cor amarela, comumente chamados de "PostIt $\AA^{2}$ "“. Tais ilustrações se relacionam a determinadas atribuições profissionais.

\footnotetext{
${ }^{2}$ Blocos de papel com um adesivo de característica singular, que adere suavemente às superfícies e pode ser facilmente removido e recolocado. Fonte: <http://www.postit.com.br/wps/portal/3M/pt_BR/LAPost-it/Global/About/About/>. Acesso em: 21 mar. 2016.
} 
EID\&A - Revista Eletrônica de Estudos Integrados em Discurso e Argumentação, Ilhéus, n. 12, jul/dez.2016.

Podemos depreender, assim, que o calendário, bem como o relógio, representa a execução de serviços típicos de escritório, como o registro de compromissos (os quais têm dia e hora determinados), tarefa condizente com as atribuições profissionais da secretária da década de 50. Em tal época, as funções dessa profissional eram majoritariamente técnicas e, com a lei de regulamentação da profissão, Lei $n^{\circ} 7377 / 85$, complementada pela Lei $n^{\circ}$ 9261/96, tal competência cabe ao profissional de secretariado em nível de segundo grau (técnico). Por outro lado, essas mesmas imagens também poderiam representar, a nosso ver, atividades de planejamento e organização de serviços de secretaria, função que concerne ao profissional de secretariado executivo (em nível de terceiro grau), o qual, a partir da década de 80, passou a ter atribuições de caráter estratégico. Isso porque, em nossos imaginários, as figuras de calendário e relógio denotam data e horário, respectivamente, elementos relacionados a planejamento no âmbito empresarial.

Logo abaixo da ilustração do relógio, há uma imagem que remete a uma reunião de pessoas. Em nossa compreensão, tal imagem pode ser relacionada à competência de assessoramento direto ao executivo (em ocasióes diversas, sendo a reunião uma delas), atribuição não só prevista em lei como concernente ao secretário executivo, mas também associada ao imaginário sociodiscursivo do profissional secretarial (secretário/secretário executivo) como o responsável pela organização de reuniões do superior/da empresa. Ainda aqui, é possível fazermos uma associação da imagem com a atividade de redação de textos profissionais especializados pelo secretário executivo (conforme prevê a Lei de Regulamentação da Profissão), posto que em reuniões comumente são redigidas Atas para se registrarem as decisões e ocorrências.

À direita do calendário, temos a imagem de um telefone, o que nos remete à atribuição de atendimento telefônico (e, por conseguinte, ao registro de informações e recados). Abaixo do telefone há o desenho de uma espécie de maleta. É possível fazermos uma associação entre essa imagem e a atribuição de assessoramento direto a executivos, pois, conforme a Lei de Regulamentação da Profissão, cabe ao profissional de secretariado executivo assistir diretamente seu superior, realizando atividades como a seleção e organização de documentos, os quais são carregados, em nossos imaginários, em pastas/maletas. É curioso, por outro lado, mencionarmos que tal ilustração também pode nos remeter à resolução de assuntos particulares dos 
EID\&A - Revista Eletrônica de Estudos Integrados em Discurso e Argumentação, Ilhéus, n. 12, jul/dez.2016.

executivos, dado que se pode pensar que tal maleta traga documentos de cunho pessoal, e não profissional. Desse modo, novamente temos uma mesma imagem carregando uma dualidade de imaginários: há alusão tanto às competências de secretários executivos, essas definidas a partir de 1980, quanto às de profissionais secretários dos anos 1950. Cabe ressaltar que a resolução de assuntos particulares dos superiores ainda está presente em nossos imaginários como uma das funções de um secretário/secretário executivo.

Na última imagem nos "Post-It®”, evidencia-se o símbolo “@”, que nos remete à atribuição de redação de e-mails - a qual tem sua origem na datilografia ${ }^{3}$. Essa atividade é de competência tanto de secretários como de secretários executivos, uma vez que a Lei de Regulamentação traz, como atribuição do primeiro, elaboração de correspondências e documentos de rotina e, como incumbência do segundo, redação de textos profissionais especializados (com o advento da tecnologia, as empresas utilizam o e-mail como uma forma de comunicação específica).

Nesse viés, comprovamos o que postula Medina (2013): uma mesma imagem pode evocar diferentes efeitos de sentido. No caso do nosso trabalho, diferentes imaginários sociodiscursivos. Em nosso objeto de estudo, evidenciamos, logo, que uma mesma imagem remete a competências tanto de secretários como de secretários executivos, como, por exemplo, o próprio “@”, sobre o qual discorremos. Dessa maneira, a publicidade por nós estudada toma o secretariado e o secretariado executivo como uma profissão única, sem distinção entre essas duas categorias e suas respectivas incumbências, o que reforça o imaginário socialmente cristalizado de que ambas constituem uma só categoria profissional, ainda que as atribuições específicas de cada categoria sejam distintas, conforme estabelecido pelo Art. $4^{\circ}$ da Lei de Regulamentação n 7377/85, complementada pela Lei no 9261/96.

É curioso observarmos que o fundo da peça publicitária traz traços que compõem uma espécie de flor. Essa imagem corrobora com o imaginário veiculado acerca da concepção da profissão secretarial como essencialmente feminina, uma vez que, em nossos imaginários sociodiscursivos, flores são presentes frequentemente dados a mulheres. Esse imaginário, segundo anteriormente o dissemos, foi evidenciado também no artefato verbal, posto

${ }^{3}$ Digitação em máquinas de escrever. 
EID\&A - Revista Eletrônica de Estudos Integrados em Discurso e Argumentação, Ilhéus, n. 12, jul/dez.2016.

que fora utilizada a palavra "Secretárias" para se referir à categoria profissional.

Atendo-nos agora às cores utilizadas, constatamos que, na maioria, foram empregados o amarelo (nos Post-lt ${ }^{\circledR}$ ), o marrom-claro (no plano de fundo da peça), o branco (na moldura do logotipo e no nome da empresa), o verde (na constituição do logotipo da Unimed e das certificações por essa recebidas) e o preto (nas ilustrações e nos dizeres). A cor amarela, para Guimarães (2000), é eficaz para atrair a atenção, além de, fisiologicamente, estimular a atividade mental. Aumenta os processos de análise e o raciocínio lógico, auxiliando na tomada de decisões. É importante pontuar que a tomada de decisões junto ao executivo é uma das atribuições do profissional de secretariado executivo, conquistada na década de 80, com o advento da Administração Participativa. Já o marrom, utilizado em gradação clara, sugere resistência, dever e estabilidade (PORTAL DO MARKETING NET). Tais atributos, de certa forma, estariam atrelados ao profissional "ideal, desejável" da área secretarial, posto que se espera deste o compromisso e a responsabilidade para com a empresa e para com o corpo executivo para o qual trabalha.

O branco, utilizado como moldura do nome da empresa, tem a função de delinear o contorno da imagem que traz a Unimed, assim como de grafar esse termo. Essa cor remete à ideia de paz, como aponta Reis (2012), e também sugere segurança. Remete ainda a organização e eficiência' As características dessa cor sugerem, assim, as próprias qualidades da empresa Unimed, pois foram utilizadas justamente (e apenas) em alusão à corporação. Essa cor constitui, junto com o verde (PORTAL DO MARKETING NET) - que é associado, em nossos imaginários, às ideias de esperança ou à natureza, podendo também evocar sensações de bem-estar, segurança -, as cores do logotipo da Unimed, fazendo alusão a paz, confiança, segurança e bem-estar, características que constroem, portanto, a imagem da empresa. O verde, inclusive, é empregado no enunciado: "Viva a vida. Viva Unimed", que figura no logotipo.

Em relação à cor preta, identificamo-la nos aportes textuais: "Secretárias, parabéns pelo dia de hoje. Nosso trabalho seria impossível sem o de vocês" e "30 de setembro. Dia da Secretária". Essa cor, em nossos imaginários, relaciona-se a sobriedade e seriedade (REIS, 2012) e, de acordo com Guimarães (2000), está ligada às ideias de respeito e autoridade, 
EID\&A - Revista Eletrônica de Estudos Integrados em Discurso e Argumentação, Ilhéus, n. 12, jul/dez.2016.

particularidades diretamente relacionadas à imagem que a Unimed intenta estabelecer junto a seu TUd.

Voltando ao enunciado "Viva a Vida. Viva Unimed", podemos dizer, ainda, que a empresa busca estabelecer uma relação de empatia para com seu público, porque, mesmo sendo do ramo de planos de saúde - dos quais comumente necessitamos em momentos de enfermidade -, a organização coloca (e festeja) a vida, representada em sua fala. Viver a vida, nesse sentido, seria viver a saúde, logo, a Unimed busca veicular a imagem de que, mais do que planos de saúde, ela vende bem-estar.

Por fim, temos, na parte inferior direita da peça publicitária, três selos de certificações. Da esquerda para a direita, são: Selo Responsabilidade Social, concedido pela Unimed do Brasil e pela Fundação Unimed em 2008 a 192 Unimeds que promoveram a conscientização para uma sociedade mais justa e sustentável (UNIMED DO BRASIL); Selo Fundação Abrinq - Empresa Amiga da Criança -, que reconhece empresas que realizam ações sociais para a promoção e a defesa dos direitos de crianças e adolescentes ${ }^{4}$, e o Selo da ANS - Agência Nacional de Saúde Suplementar -, que certifica o registro da Unimed Araraquara nessa Agência, vinculada ao Ministério da Saúde Brasileiro, responsável pela regulação (criação de normas, controle e fiscalização) dos planos de saúde do país ${ }^{5}$. É importante ressaltar que a exibição desses selos na composição da publicidade busca conferir credibilidade à Unimed Araraquara, mais uma ferramenta de busca da reafirmação da imagem (positiva) da organização.

\section{Considerações Finais}

A partir da análise empreendida, pudemos identificar imaginários concernentes tanto aos profissionais de secretariado como aos de secretariado executivo nessa publicidade da Unimed.

Averiguamos, assim, que uma mesma imagem faz referência a diferentes imaginários. Verificamos uma retratação de imaginários da profissão ancorados na Lei $n^{\circ} 7377 / 85$, complementada pela Lei $n^{\circ}$ 9261/96, relacionados, pois, aos saberes de conhecimento. Desse modo, observamos os imaginários

\footnotetext{
${ }^{4}$ Fonte: < http://www.fundabrinq.Org.br/protecao/protecao-empresa-amiga-da-crianca>. Acesso em: 15 set. 2016.

${ }^{5}$ Fonte: <http://www.ans.gov.br/aans/quem-somos>. Acesso em: 15 set. 2016.
} 
EID\&A - Revista Eletrônica de Estudos Integrados em Discurso e Argumentação, llhéus, n. 12, jul/dez.2016.

concernentes à execução de serviços típicos de escritório, tais como registros de compromissos e informações, além de atendimento telefônico, atrelados às imagens do calendário, do relógio e do telefone, relativos, portanto, às atribuições do profissional (técnico) de secretariado. Por outro lado, averiguamos também o imaginário relacionado a planejamento e organização de serviços de secretaria, o qual pode ser evocado pelo calendário e pelo relógio; a assistência e assessoramento direto a executivos, dada a maleta; e a redação de textos profissionais especializados, tendo em vista o “@” e a imagem que faz alusão a uma reunião. Essas duas últimas atribuições competem ao secretário executivo, como descrito na Lei.

Além disso, constatamos que as cores corroboraram para a instauração dos efeitos de sentido, dado que estabelecem significâncias numa dada situação de comunicação. O significado das cores está atrelado ao fator cultural, à situação e à intenção de comunicação (GUIMARÃES, 2000). Logo, as cores utilizadas se relacionaram às ideias de formalidade, atenção, estabilidade e organização, atributos esperados (desejados) de um profissional secretarial. Portanto, há um reforço no que diz respeito aos imaginários relacionados aos predicados que compõem/devem compor o perfil de secretários e secretários executivos. Além disso, observamos também o uso das cores verde e branco, encontradas exclusivamente no logotipo da Unimed, que evocam sentidos de segurança, organização e bemestar, utilizadas para remeter, assim, às características que se relacionam diretamente com a organização. Dessa maneira, tem-se a construção de uma imagem da empresa como detentora de tais qualidades.

Finalmente, os imaginários sociodiscursivos cristalizados mostraram-se presentes na tomada da profissão como feminina - dado o emprego do gênero feminino na palavra "Secretárias" e a utilização de uma flor como constituinte do plano de fundo da peça -, com atribuições tecnicistas - tendo em vista a alusão das imagens a serviços de escritório rotineiros - e, há que se destacar, sem uma distinção entre as duas categorias profissionais: a de secretariado e a de secretariado executivo. Assim, ambas as categorias são representadas, nessa publicidade, como se constituíssem uma só, ou, ainda, como se todas as atribuições ali presentes fossem do secretário e/ou do secretário executivo. Esse último imaginário foi averiguado nas imagens que remetem às atividades profissionais, imagens essas que evocam diferentes efeitos de sentido (MEDINA, 2013). 
EID\&A - Revista Eletrônica de Estudos Integrados em Discurso e Argumentação, Ilhéus, n. 12, jul/dez.2016.

\section{Referências}

BRASIL. Lei $n^{\circ}$ 9.261, de 10 de janeiro de 1996. Altera a redação dos incisos I e II do art. $2^{\circ}$, o caput do art. $3^{\circ}$, o inciso VI do art. $4^{\circ}$ e o parágrafo único do art. $6^{\circ}$ da Lei $n^{\circ} 7$. 377, de 30 de setembro de 1985. Diário Oficial da União, Brasília, 11 jan. 1996.

BRASIL. Lei $n^{\circ} 7.377$, de 30 de setembro de 1985 . Dispõe sobre o Exercício da Profissão de Secretário, e dá outras Providências. Diário Oficial da União, Brasília, 1 out. 1985.

CHARAUDEAU, Patrick. Visadas discursivas, gêneros situacionais e construção textual. In: MACHADO, Ida Lúcia; MELLO, Renato (Org.). Gêneros: Reflexões em Análise do Discurso. Belo Horizonte: NAD/FALE/UFMG, 2004. p. 14-41.

- Da ideologia aos imaginários sociodiscursivos. In: CHARAUDEAU, Patrick. Discurso Político. São Paulo: Contexto, 2008a. p. 187-208.

. Linguagem e discurso: modos de organização. Trad. Angela M. S. Correa \& Ida Lúcia Machado. São Paulo: Contexto, 2008b.

GUIMARÃES, Luciano. A cor como informação: a construção biofísica, linguística e cultural da simbologia das cores. São Paulo: Annablume, 2000.

MEDINA, Leonardo Cézar Correa. Metaimagens e AD: Análise da Vinheta de Abertura do CQC - Custe o que Custar - 2010. In: MACHADO, Ida Lúcia, LIMA, Helcira; LYSARDO-DIAS, Dylia (Org.). Imagem e Discurso. Belo Horizonte: NETII - FALE/UFMG, 2013. p. 307-322.

MELO, Mônica Santos de Souza. Estratégias Discursivas em Publicidades Televisivas de Medicamentos. In: GOMES, Maria Carmen Aires; CATALDI, Cristiane; MELO, Mônica Santos de Souza (Org.). Estudos Discursivos em Foco: práticas de pesquisa sobre múltiplos olhares. Viçosa: Editora UFV, 2011. p. 189-206.

PAULIUKONIS, Maria Aparecida Lino; GOUVÊA, Lúcia Helena Martins. Texto como discurso: uma visão semiolinguística. Revista do Programa de Pós-Graduação em Letras da Universidade de Passo Fundo, v. 8 - n. 1, p. 49-70, jan./jun. 2012. Disponível em: <http://www.upf.br/seer/index.php/rd/article/download/2638/1800>. Acesso em: 27 set. 2016.

REIS, Ana Carolina Gonçalves. Imagens e Imaginários da profissão de secretariado na revista Excelência. 2012. Dissertação (Mestrado em Estudos Linguísticos). UFMG: Belo Horizonte/MG, 2012.

SABINO, Rosimeri Ferraz; ROCHA, Fabio Gomes. Secretariado: do escriba ao web writer. 1. ed. Rio de Janeiro: Brasport, 2004. 
EID\&A - Revista Eletrônica de Estudos Integrados em Discurso e Argumentação, llhéus, n. 12, jul/dez.2016.

\section{Fontes}

UNIMED DO BRASIL. Portal Nacional de Saúde. Sobre a Unimed. Disponível em: <http://www.unimed.coop.br/pct/index.jsp?cd_canal=49146\&cd_secao=49094>. Acesso em: 07-4-2016.

UNIMED ARARAQUARA. Nossa História. Disponível em: <http://www.unimedara.com.br/index.php?id=200>. Acesso em: 7 abr. 2016.

UNIMED. Anúncio secretária. Gabriel Portifolio. Flickr. Disponível em: <https://www.flickr.com/photos/gabrielportifolio/5463000106/?rb=1>. Acesso em: 7 abr. 2016.

POST- IT® BRAND. Produtos. Sobre o Post- It ${ }^{\circledR}$. Disponível em: <http://www.postit.com.br/wps/portal/3M/pt_BR/LAPost-it/Global/About/About/>. Acesso em: 21 mar. 2016.

PORTAL DO MARKETING NET. Significado das Cores. Disponível em: <http://www.portaldomarketing.net.br/?s=significado+das+cores\&submit=Pesquisa >. Acesso em: 3 abr. 2016.

Forma de citação sugerida:

REIS, Ana Carolina Gonçalves; FONSECA, Anna Clara Arcanjo. 30 de setembro, dia da secretária: análise discursivo-imagético-textual de publicidade on-line da UNIMED Araraquara. EID\&A - Revista Eletrônica de Estudos Integrados em Discurso e Argumentação, Ilhéus, n. 12, p. 1-17, jul/dez.2016.

Recebido em: 29/10/2016

Aprovado em: 06/12/2016 